\title{
Analisis Faktor Penyebab Terjadinya Kecelakaan Kerja Pada Pekerja di Unit Spinning Perusahaan Manufaktur Kota Cirebon
}

\author{
Mitha Erlisya Puspandhani \\ STIKes Mahardika Cirebon \\ Coresponding Autor: mitha_m3p@yahoo.com
}

\begin{abstract}
Abstrak : Perusahaan Manufaktur ini adalah perusahaan yang bergerak dalam bidang industri tekstil pemintalan benang cotton. Dalam proses pemintalan benang menggunakan mesin-mesin yang memiliki potensi kecelakaan cukup besar dilihat dari kecelakaan kerja di Perusahaan manufaktur kota Cirebon dari tahun 2012 sampai dengan tahun 2014 terdapat kasus kecelakaan kerja sebanyak 47 kasus. Tujuan penelitian ini adalah menganalisis hubungan faktor - faktor penyebab terjadinya kecelakaan kerja pada pekerja di unit Spinning Perusahaan Manufaktur Kota Cirebon. Penelitian ini merupakan penelitian Eksplanatory Research dengan menggunakan rancangan Cross Sectional Study. Populasi ini adalah seluruh pekerja yang bekerja di unit spinning Perusahaan Manufaktur Kota Cirebon yang berjumlah 441 orang. Metode pengambilan sampel dalam penelitian ini menggunakan purposive sampling sehingga didapatkan sampel penelitian dengan jumlah 94 orang. Pengumpulan data dengan menggunakan kuesioner dan observasi langsung, data yang diperoleh kemudian diolah secara statistik menggunakan teknik analisis distribusi frekuensi, uji chi square serta analisis regresi logistik. Hasil penelitian menunjukan bahwa 20,2\% mengalami kecelakaan kerja di uni spinning. Variabel yang berhubungan dengan kecelakaan kerja adalah masa kerja ( $p$-value $=0,021)$, shift kerja ( $p$-value $=0,021)$, beban kerja ( $p$-value $=0,024)$, dan unit kerja dengan $(p$-value $=0,027)$, variabel yang paling berpengaruh terhadap kecelakaan kerja pada pekerja diunit spinning adalah shift kerja (Exp (B) $=5,733$ ). Disarankan bagi perusahaan untuk memberikan pengarahan mengenai keselamatan kerja (safety induction) bagi pekerja baru lebih difokuskan pada bahaya dan risiko pekerja pada unit kerja yang akan ditempati serta perusahaan dapat mencukupi ketersediaan APD di unit spinning, menegakan fungsi kontrol dan evaluasi dalam penyediaan APD pada pekerja dan bagi pekerja agar menggunakan APD sesuai dengan SOP yang ada di perusahaan secara konsisten dan sesuai aturan.
\end{abstract}

Kata Kunci : kecelakaan kerja, perusahaan manufaktur di unit spinning.

\section{The Analysis Of Workplace Accident Agent To Workers In The Spinning Unit Of Manufacturing Company in Cirebon City}

\author{
Mitha Erlisya Puspandhani \\ STIKes Mahardika Cirebon \\ Coresponding Autor: mitha_m3p@yahoo.com
}

\begin{abstract}
The Manufacturing Company is business textile industry that is engaged in spinning yarn of cotton. In the process of spinning, it is used by machines that have the potential for accidents big enough, it can be looked by work accidents from 2012-2014. It was found the cases of work accidents by 47 cases. The research is amed to analyze the correlation of factor accidents agent from the worker in the spinning unit of manufacturing company in Cirebon.This research is eksplanatory research by using device of cross sectional study. Populasi in workers in the spinning unit of manufacturing company in Cirebon as much 94 worker. The data is collected by using questionnaires and observation direct, the data that collected was analyzed whit statistic data by using analysis thechnique of frequency distribution, test of chi squere and analysis of regresi logistic. Result of the research that showed 20,2\% injured of work in spinning unit variable that have correlation whit work accident is years of service ( $p$-value $=0,021)$, shift of work ( $p$-value $=0,021)$, workload ( $p$-value $=0,024)$, and work unit ( $p$-value $=0,027)$. The variable that influence on work accidents to worker in the spinning shift of work $(\operatorname{Exp}(B)=5,733)$.Advisable for the company to provide guidance about safety induction, for new workers are more focused at the dangers and the risks to the workers that will be assigned to unit, and the company can be sufficient availability of APD in the spinning unit. It can build control and evaluation in the supplying of APD to workers in order to uses APD that appropriate whit SOP that exists in the company in consistently manner and appropriate by regulation.
\end{abstract}

Keywords : workplace accidents, in the spinning unit of manufacturing company

\section{PENDAHULUAN}

Keselamatan merupakan perhatian universal dan menjadi tanggung- jawab semua pihak. Pernyataan ini mengemuka dalam Manifesto for Safe Communities Organisasi Kesehatan Dunia (WHO) 1989 di Stockholm, Swedia dalam konferensi Internasional pertama tentang pencegahan kecelakaan dan cidera. Dalam manifesto ini juga meyatakan bahwa semua manusia memiliki hak yang sama atas kesehatan dan keselamatan. Prinsip kebijakan sosial ini merupakan dasar pemikiran Health for All Strategy dan Global Program WHO mengenai pengendalian cidera dan pencegahan kecelakaan.

Kesehatan dan keselamatan kerja merupakan bagian urgensial dalam sebuah perusahaan. Dalam hal upaya pemantauan, pengukuran, pengendalian resiko hingga tindakan pencegahan terhadap hal yang paling tidak diinginkan perusahaan yakni kecelakaan. Menurut Fank Bird, an accident is undesired event that result in physical 
harm to a person or demage to property. It is usually the result of a contact whith a source of energy (kinetic, electrical, chemical, thermal etc).

Menurut estimasi laporan Internasional Labour Organization (ILO) tahun 2012, diseluruh dunia terjadi lebih dari 2,34 juta kasus kecelakaan dalam pekerjaan pertahun. Sedangkan menurut data Kemenakertrans tahun 2012, terdapat angka kecelakaan kerja di Indonesia pada tahun 2011 mencapai 96.314 kasus. Sedangkan untuk tingkatan provinsi, provinsi Jawa Barat menempati urutan ketiga kasus terbanyak yaitu dengan jumlah kecelakaan mencapai 1773 kasus pertriwulan II tahun 2012.

Menurut data PT. Jamsostek, kasus kecelakaan kerja pada tahun 2008 naik sebesar 12,08 persen menjadi 93.823 kasus dengan pembayaran klaim Rp.269,4 miliar sedangkan tahun 2009 tercatat sebanyak 96.314 kasus dengan pembayaran klaim sebesar Rp.328.51 miliar. Dan pada tahun 2010 tercatat jumlah kasus 98.711 kasus dengan pembayaran klaim sebesar 401 miliar. Kecelakaan kerja yang terjadi banyak yang diakibatkan oleh kondisi tidak aman yakni sebesar 57.626 kasus (58,15\%) dari total kasus selama 2009. Selain faktor kondisi tidak aman, kecelakaan kerja juga kerap terjadi akibat kesalahan tenaga kerja yang bersangkutan atau sering kali disebut sebagai tindakan yang tidak aman.

Dari pernyataan diatas nampak jelas bahwa kecelakaan akan mengakibatkan kerugian yang tidak sedikit bagi pekerja maupun perusahaan. Dewasa ini, para perusahaan sudah menyadari betapa pentingnya keselamatan dan kesehatan kerja yang terintegritas. Kesadaran ini termanifestasi dalam berbagai upaya pengendalian dan program K3. Namun sayangnya, kesadaran akan pentingnya K3 belum sampai pada tingkatan yang optimal. Perusahaan menyadari K3, namun pekerja belum sepenuhnya mengerti dengan K3 sehingga upaya program K3 pun bagai berdiri dengan kaki sebelah, belum ada keseimbangan dalam implementasi program K3. Hal ini dapat terlihat dari tingkat pengetahuan pekerja terhadap K3 masih rendah dan masih tingginya angka kecelakaan pekerja di Indonesia.

Berdasarkan hasil wawancara yang dilakukan, unit spinning adalah salah satu tempat yang mempunyai risiko terhadap terjadinya kecelakaan kerja. Begitu pula hasil data kecelakaan Kerja Perusahaan Manufaktur kota Cirebon dari bulan Januari tahun 2012 sampai bulan Desember 2014 menunjukkan terjadinya angka kasus kecelakaan di gudang dan kecelakaan kerja terjadi di unit Spinning sebanyak 47 kasus. Berdasarkan observasi lapangan yang dilakukan peneliti pada proses carding dan proses ring spinning masih terdapat beberapa pekerja tidak menggunakan APD (masker). Menurut penuturan salah satu pekerja alasan tidak memakai APD dikarenakan panas, sumpek, ribet dan tidak nyaman. Begitu juga dengan hasil studi pendahuluan yang telah dilakukan peneliti terdapat karakteristik pekerja seperti (usia, masa kerja, jenis kelamin, pendidikan) dan shift kerja, beban kerja serta unit kerja dicurigai sebagai faktor penyebab terjadinya kecelakaan. Selain faktor tersebut Unsafe act seperti ketidak patuhan SOP dan masih terdapat beberapa pekerja yang tidak memakai APD dicurigai menjadi salah satu faktor utama penyumbang terbesar terjadinya kecelakaan di unit spinning Perusahaan Manufaktur Cirebon.

\section{Metode Penelitian}

Jenis penelitian ini adalah Explanatory Research (penjelasan) dengan maksud menjelaskan hubungan antara variabel-variabel melalui pengujian hipotesis sedangkan metode penelitian adalah dengan melakukan observasi dan wawancara. Penelitian ini menggunakan pendekatan cross sectional study.

\section{Analisis Data}

Untuk mengetahui frekuensi, distribusi dan korelasi variabel-variabel penelitian terhadap faktor-faktor penyebab kecelakaan kecelakaan pada pekerja, dilakukan analisis data sebagai berikut:

\section{Analisa Univariat}

Analisis univariat digunakan untuk mendeskripsikan variabel penelitian baik variabel independen maupun variabel dependen, menggunakan distribusi frekuensi.

\section{Analisa Bivariat}

Analisis bivariat digunakan untuk mengetahui korelasi antara masing-masing variabel independen secara parsial terhadap variabel dependen. Analisis bivariat dengan cara:

\section{1) Tabulasi silang}

Tabulasi silang pada prinsipnya bertujuan untuk menyajikan data dalam bentuk tabel yang meliputi baris dan kolom. Analisis dilakukan untuk melihat pola atau kecenderungan hubungan 2 (dua) variabel yang diteliti dan dibuat dalam bentuk tabel distribusi dari variabel penelitian.

\section{2) Uji Hipotesis}

Hubungan antara variabel bebas dengan variabel terikat dianalisis dengan Chi Square. Uji statistik ini dapat menimbulkan adanya hubungan dua variabel berdasarkan perbandingan $\rho$ atau tingkat kepercayaan dengan taraf signifikan atau alpha (a) $5 \%$ atau 0,05 . 
Bila $\rho<0,05$, maka Ho berarti ada hubungan antara usia, pendidikan, masa kerja, jenis kelamin, unit kerja, shift kerja, beban kerja, kepatuhan SOP, dan pemakaian APD dengan terjadinya kecelakaan kerja pada pekerja di unit spinning.

Bila $\rho>0,05$, maka berarti tidak ada hubungan antara usia, pendidikan, masa kerja, jenis kelamin, unit kerja, shift kerja, beban kerja, kepatuhan SOP, dan pemakaian APD dengan terjadinya kecelakaan kerja pada pekerja di unit spinning.

\section{Analisis Multivariat}

Pada analisis multivariat, dilakukan terhadap lebih dari dua variabel. Biasanya hubungan antara satu variabel terikat (dependent variabel) dengan beberapa variabel bebas (independent variabel). Anlisis ini merupakan perluasan dari analisis univariat dan bivariat. Analisis multivariat dilakukan melalui uji regresi logistik untuk melihat hubungan variabel-variabel bebas dengan variabel terikat dan variabel bebas mana yang paling besar pengaruhnya terhadap variabel terikat. Syarat dari penggunaan uji regresi logistik ini adalah analisis bivariatnya dengan Chi Square Test, variabel kategorik dan analisis bivariat mempunyai nilai $\mathrm{p}<0,05$.

Analisis multivariat dilakukan dengan cara menghubungkan beberapa variabel bebas dengan satu variabel terikat secara bersamaan. Analisis regresi logistik dimulai dengan memasukkan semua variabel yang mempunyai nilai $\mathrm{p}<0,05$ pada analisis bivariat dengan menggunakan metode backward LR. Jika ada variabel dengan nilai $p>$ 0,05 ; kovariat/ variabel tersebut tetap dimasukan ke dalam model multivariat.

\section{HASIL PENELITIAN}

\section{A. Hasil Analsis Univariat}

1. Gambaran Usia Pekerja

Tabel 4.1.

Distribusi Frekuensi Responden Berdasarkan Usia

\begin{tabular}{|c|c|c|c|}
\hline No & Usia & Frekuensi (f) & Persentase (\%) \\
\hline 1 & Remaja Lanjut (19-21 tahun) & 8 & 8.5 \\
\hline 2 & Dewasa Muda (22-40 tahun) & 86 & 100.0 \\
\hline \multicolumn{2}{|c|}{ Total } & 94 & \\
Median : 28 & & \\
\hline
\end{tabular}

Berdasarkan data yang tercantum pada tabel 4.1 diatas, dapat diketahui bahwa reponden yang memiliki usia, remaja lanjut (19-21 tahun) sebanyak 8 orang dengan persentase sebesar (8,5\%) sedangkan responden yang memiliki usia dewasa muda (22-40 tahun) sebanyak 86 dengan persentase sebesar (91,5\%). Rata-rata usia responden adalah 28 tahun, usia responden paling muda adalah berusia 19 tahun dan responden yang paling tua berusia 40 tahun.

2. Gambaran Pendidikan Pekerja 
Tabel 4.2.

Distribusi Frekuensi Responden Berdasarkan Pendidikan

\begin{tabular}{|c|c|c|c|}
\hline No & Pendidikan & Frekuensi (f) & Persentase (\%) \\
\hline 1 & SMU & 64 & 68.1 \\
\hline 2 & SMP & 30 & 100.0 \\
\hline \multicolumn{2}{|c|}{ Total } & 94 & \\
\hline
\end{tabular}

Berdasarkan data yang tercantum pada tabel 4.2 diatas, dapat diketahui bahwa reponden yang memiliki tingkat pendidikan SMU sebanyak 64 orang dengan persentase sebesar $(68,1 \%)$ sedangkan responden yang memiliki tingkat pendidikan SMP sebanyak 30 orang dengan persentase sebesar $(31,9 \%)$.

3. Gambaran Masa Kerja Pekerja

Tabel 4.3.

Distribusi Frekuensi Responden Berdasarkan Masa Kerja

\begin{tabular}{|c|l|c|c|}
\hline No & \multicolumn{1}{|c|}{ Masa Kerja } & Frekuensi (f) & Persentase (\%) \\
\hline 1 & $\geq 6.5$ tahun & 47 & 50.0 \\
\hline 2 & $<6.5$ tahun & 47 & 50.0 \\
\hline \multicolumn{1}{|c|}{ Total } & 94 & 100.0 \\
\hline $\begin{array}{l}\text { Min - Max: } 1 \text { tahun }-10 \text { tahun Mean : } \\
6 \text { tahun } \\
\text { Median : } 6,5 \text { tahun }\end{array}$ & & \\
\hline
\end{tabular}

Berdasarkan data yang tercantum pada tabel 4.3 diatas, dapat diketahui bahwa reponden yang memiliki masa kerja $\geq 6.5$ tahun sebanyak 47 orang dengan persentase sebesar (50\%) sedangkan responden yang memiliki masa kerja $<6.5$ tahun sebanyak 47 orang dengan persentase sebesar (50.0\%). Rata-rata masa kerja pada responden adalah 6 tahun dan masa kerja baru adalah 1 tahun dan responden yang masa kerjanya paling lama adalah 10 tahun.

4. Gambaran Jenis Kelamin Pekerja

Tabel 4.4.

Distribusi Frekuensi Responden Berdasarkan Jenis Kelamin

\begin{tabular}{|c|c|c|c|}
\hline No & Jenis Kelamin & Frekuensi (f) & Persentase (\%) \\
\hline 1 & Pria & 55 & 58.5 \\
\hline 2 & Wanita & 39 & 41.5 \\
\hline \multicolumn{2}{|c|}{ Total } & 94 & 100.0 \\
\hline
\end{tabular}

Berdasarkan data yang tercantum pada tabel 4.4 diatas, dapat diketahui bahwa reponden yang berjenis kelamin pria sebanyak 55 orang dengan persentase sebesar $(58,5 \%)$ sedangkan responden yang berjenis kelamin wanita sebanyak 39 orang dengan persentase sebesar (41,5\%).

5. Gambaran Shift Kerja Pada Pekerja

Tabel 4.5.

Distribusi Frekuensi Responden Berdasarkan Shift Kerja

\begin{tabular}{|c|c|c|c|}
\hline No & Shift Kerja & Frekuensi (f) & Persentase (\%) \\
\hline 1 & Pagi, Siang & 65 & 69.1 \\
\hline 2 & Malam & 29 & 30.9 \\
\hline \multicolumn{2}{|r|}{ Total } & 94 & 100.0 \\
\hline
\end{tabular}

Berdasarkan data yang tercantum pada tabel 4.5 diatas, dapat diketahui bahwa reponden yang berada pada shift pagi, shift siang sebanyak 65 orang dengan persentase sebesar (69.1\%), Sedangkan responden yang berada pada shift malam sebanyak 29 orang 
dengan persentase sebesar (30,9\%).

6. Gambaran Beban Kerja Pada Pekerja

Tabel 4.6.

Distribusi Frekuensi Responden Berdasarkan Beban

\begin{tabular}{|c|c|c|c|}
\hline No & Beban Kerja & Frekuensi (f) & Persentase (\%) \\
\hline 1 & Ringan & 36 & 38.3 \\
\hline 2 & Sedang & 58 & 61.7 \\
\hline \multicolumn{2}{|c|}{ Total } & 94 & 100.0 \\
\hline
\end{tabular}

Dalam penelitian beban kerja ini menggunakan alat ukur "Fingertip Oximeter" serta pengukurannya dengan menggunakan rumus \% CVL. Untuk mempermudah dalam menganalisi maka peneliti mengkategorikan beban kerja menjadi dua yaitu beban kerja ringan dengan ( klasifikasi < 30\%) dan beban kerja sedang dengan (klasifikasi 30 s.d $<60 \%$ ).

Dari tabel 4.6 diatas, dapat diketahui bahwa reponden yang memiliki beban kerja ringan sebanyak 36 orang dengan persentase sebesar (38.3\%) sedangkan responden yang memiliki beban kerja sedang sebanyak 58 orang dengan persentase sebesar (61.7\%).

7. Gambaran Unit Kerja Pada Pekerja

Tabel 4.7.

Distribusi Frekuensi Responden Berdasarkan Unit Kerja

\begin{tabular}{|c|c|c|c|}
\hline No & Unit Kerja & Frekuensi (f) & Persentase (\%) \\
\hline 1 & Pre Spinning & 34 & 36.2 \\
\hline 2 & Ring Spinning, & 60 & 63.8 \\
& Winding & & 100.0 \\
\hline
\end{tabular}

Berdasarkan data yang tercantum pada tabel 4.7 diatas, dapat diketahui bahwa reponden yang berada pada unit pre spinning sebanyak

34 orang dengan persentase sebesar (36,2\%), sedangkan responden yang berada pada unit ring spinning, winding sebanyak 60 orang dengan persentase sebesar (63.8\%).

8. Gambaran Kepatuhan SOP Pada Pekerja

Tabel 4.8.

Distribusi Frekuensi Responden Berdasarkan Kepatuhan SOP

\begin{tabular}{|c|c|c|c|}
\hline No & $\begin{array}{c}\text { Kategori } \\
\text { Kepatuhan SOP }\end{array}$ & Frekuensi (f) & Persentase (\%) \\
\hline 1 & Patuh & 47 & 50,0 \\
\hline 2 & Tidak Patuh & 47 & 50,0 \\
\hline \multicolumn{1}{|c|}{ Total } & 94 & 100.0 \\
\hline $\begin{array}{l}\text { Mean }: 45 \quad \\
\text { Min - Max : } 28-64\end{array}$ & & \\
\hline
\end{tabular}

Dari tabel 4.8 tersebut menunjukan bahwa hampir sebagian responden patuh dalam penerapan kepatuhan SOP 50,0\% sebanyak 47 orang dan sebagian besar tidak patuh 50,0\% sebanyak 47 orang. Rata- rata nilai kepatuhan SOP responden adalah 45 dengan nilai tengah 43,5. Nilai kepatuhan SOP yang paling rendah adalah 28 dan paling tinggi 64 .

9. Gambaran Pemakaian APD Pada Pekerja 
Tabel 4.9.

Distribusi Frekuensi Responden Berdasarkan Pemakaian APD

\begin{tabular}{|c|c|c|c|}
\hline No & Pemakaian APD & Frekuensi (f) & Persentase (\%) \\
\hline 1 & Lengkap & 19 & 20.2 \\
\hline 2 & Tidak Lengkap & 75 & 79.8 \\
\hline & Total & 94 & 100.0 \\
\hline
\end{tabular}

Berdasarkan data yang tercantum pada tabel 4.9 diatas, dapat diketahui bahwa reponden yang memiliki kategori lengkap sebanyak 19 orang dengan persentase sebesar $(20,2 \%)$ sedangkan responden yang memiliki kategori tidak lengkap sebanyak 75 orang dengan persentase sebesar (79,8\%).

10. Gambaran Kecelakaan Kerja Pada Pekerja

Tabel 4.10.

Distribusi Frekuensi Responden Berdasarkan Kecelakaan Kerja

\begin{tabular}{|c|c|c|c|}
\hline No & Kecelakaan Kerja & Frekuensi (f) & Persentase (\%) \\
\hline 1 & Tidak & 75 & 79.8 \\
& Kecelakaan & & 20.2 \\
\hline 2 & Kecelakaan & 19 & 100.0 \\
\hline
\end{tabular}

Berdasarkan data yang tercantum pada tabel 4.10 diatas, dapat diketahui bahwa reponden yang terjadi kecelakaan sebanyak 19 orang dengan persentase sebesar $(20,2 \%)$ diantaranya adalah kecelakaan dikarenakan terjepit Gear Coiler sebanyak 2 orang, tercabik hantrak sebanyak 1 orang, teriris pada saat lapping sebanyak 1 orang, tertabrak pneumablo sebanyak 4 orang, tertelindas hantrak sebanyak 5 orang, kaki kejatuhan stand lap sebanyak 5 orang dan kecelakaan diakibatkan karena betis kaki tercabik licer in sebanyak 1 orang. Sedangkan responden yang tidak terjadi kecelakaan sebanyak 75 orang dengan persentase sebesar $(79,8 \%)$.

\section{B. Hasil Analsis Bivariat}

Pada analisis bivariat yang bertujuan untuk mengetahui kekuatan atau bentuk arah hubungan diantara dua variabel dan besarnya pengaruh yang disebabkan oleh variabel yang satu (variabel bebas) terhadap variabel lainnya (variabel terikat).

\section{Hubungan Usia Dengan Terjadinya Kecelakaan Kerja}

Tabel 4.11.

Tabulasi Silang Hubungan Antara Usia Dengan Terjadinya Kecelakaan Kerja

\begin{tabular}{|c|c|c|c|c|c|c|c|}
\hline \multirow{3}{*}{ No } & \multirow{3}{*}{ Usia } & \multicolumn{4}{|c|}{ Kecelakaan Kerja } & & \multirow[b]{2}{*}{ Total } \\
\hline & & \multicolumn{2}{|c|}{$\begin{array}{c}\text { Tidak } \\
\text { Kecelakaan }\end{array}$} & \multicolumn{2}{|c|}{ Kecelakaan } & & \\
\hline & & $\mathrm{F}$ & $\%$ & $\mathrm{~F}$ & $\%$ & $\mathrm{~F}$ & $\%$ \\
\hline 1. & Remaja lanjut (19-21 tahun) & 6 & 75.0 & 2 & 25.0 & 8 & 100.0 \\
\hline 2. & Dewasa muda (22-40 tahun) & 69 & 80.2 & 17 & 19.8 & 86 & 100.0 \\
\hline \multicolumn{2}{|c|}{$\rho=0.724$} & \multicolumn{6}{|c|}{$\mathrm{H}_{0}$ Diterima } \\
\hline
\end{tabular}

Berdasarkan tabel 4.11 menunjukkan bahwa proporsi responden yang mengalami kecelakaan kerja lebih banyak terjadi pada responden berusia remaja lanjut (19-21 tahun) sebesar 25.0\% dibandingkan dengan dewasa muda (22-40 tahun) dengan persentase sebesar $19.8 \%$.

Dari hasil uji statistik dengan menggunakan Chi Square dengan koreksi kontinuitas dan taraf signifikansi $5 \%$ diperoleh nilai $\rho$ value $=0.724(\rho<0.05)$, sehingga secara statistik dapat dikatakan bahwa tidak ada hubungan antara usia dengan terjadinya kecelakaan kerja. 
2. Hubungan Pendidikan Dengan Terjadinya Kecelakaan Kerja

Tabel 4.12. Tabulasi Silang Hubungan Antara Pendidikan Dengan Terjadinya

Kecelakaan Kerja

\begin{tabular}{|c|c|c|c|c|c|c|c|}
\hline \multirow{2}{*}{ No } & \multirow{2}{*}{ Pendidikan } & \multicolumn{4}{|c|}{ Kecelakaan Kerja } & \multicolumn{2}{c|}{ Total } \\
\cline { 3 - 7 } & & \multicolumn{2}{|c|}{ Tidak Kecelakaan } & \multicolumn{2}{c|}{ Kecelakaan } & \multicolumn{2}{c|}{} \\
\cline { 3 - 7 } & & $\mathrm{F}$ & $\%$ & $\mathrm{~F}$ & $\%$ & $\mathrm{~F}$ & $\%$ \\
\hline 1 & SMU & 52 & 81.2 & 12 & 18.8 & 64 & 100.0 \\
\hline 2 & SMP & 23 & 76.7 & 7 & 23.3 & 30 & 100.0 \\
\hline$\rho=0.606$ & & $\mathrm{H}_{0}$ Diterima &
\end{tabular}

Berdasarkan tabel 4.12 menunjukkan bahwa proporsi responden yang mengalami kecelakaan kerja lebih banyak terjadi pada responden dengan berpendidikan SMP dengan persentase sebesar $23.3 \%$, dibandingkan dengan pendidikan SMU yang hanya sebesar $18.8 \%$.

Dari hasil uji statistik dengan menggunakan Chi Square dengan koreksi kontinuitas dan taraf signifikansi $5 \%$ diperoleh nilai $\rho=0.606(\rho>0.05)$, sehingga secara statistik dapat dikatakan bahwa tidak ada hubungan antara pendidikan dengan terjadinya kecelakaan kerja.

\section{Hubungan Masa Kerja Dengan Terjadinya Kecelakaan Kerja}

Tabel 4.13.

Tabulasi Silang Hubungan Antara Masa Kerja Dengan Terjadinya

Kecelakaan Kerja

\begin{tabular}{|c|c|c|c|c|c|c|c|}
\hline \multirow{3}{*}{ No } & \multirow{3}{*}{ Masa Kerja } & \multicolumn{4}{|c|}{ Kecelakaan Kerja } & \multirow{2}{*}{\multicolumn{2}{|c|}{ Total }} \\
\hline & & \multicolumn{2}{|c|}{ Tidak Kecelakaan } & \multicolumn{2}{|c|}{ Kecelakaan } & & \\
\hline & & $\mathrm{F}$ & $\%$ & $\mathrm{~F}$ & $\%$ & & \\
\hline 1 & $\geq 6.5$ tahun & 42 & 89.4 & 5 & 10.6 & 47 & 100.0 \\
\hline 2 & $<6.5$ tahun & 33 & 70.2 & 14 & 29.8 & 47 & 100.0 \\
\hline \multicolumn{2}{|c|}{$\rho$ value $=0.021$} & \multicolumn{6}{|c|}{$\mathrm{H}_{0}$ Ditolak } \\
\hline
\end{tabular}

Berdasarkan tabel 4.13 menunjukkan bahwa proporsi responden yang mengalami kecelakaan kerja lebih banyak terjadi pada responden yang berada pada masa kerja $<6.5$ tahun dengan persentase sebesar $29.8 \%$, dibandingkan dengan yang berada pada masa kerja $\geq 6.5$ tahun sebesar $10,6 \%$.

Dari hasil uji statistik dengan menggunakan Chi Square dengan koreksi kontinuitas dan taraf signifikansi $5 \%$ diperoleh nilaip $==0.021(\rho<0.05)$, sehingga secara statistik dapat dikatakan bahwa ada hubungan antara masa kerja dengan terjadinya kecelakaan kerja

\section{Hubungan Jenis Kelamin Dengan Terjadinya Kecelakaan Kerja}

Tabel 4.14.

Tabulasi Silang Hubungan Antara Jenis Kelamin Dengan Terjadinya

Kecelakaan Kerja

\begin{tabular}{|c|c|c|c|c|c|c|c|}
\hline \multirow{3}{*}{ No } & \multirow{3}{*}{$\begin{array}{c}\text { Jenis } \\
\text { Kelamin }\end{array}$} & \multicolumn{4}{|c|}{ Kecelakaan Kerja } & & \\
\hline & & \multicolumn{2}{|c|}{ Kecelakaan } & \multicolumn{2}{|c|}{ Kecelakaan } & \multicolumn{2}{|c|}{ Total } \\
\hline & & $\mathrm{F}$ & $\%$ & $\mathrm{~F}$ & $\%$ & $\mathrm{~F}$ & $\%$ \\
\hline 1 & Pria & 44 & 80.0 & 11 & 20.0 & 55 & 100.0 \\
\hline 2 & Wanita & 31 & 79.5 & 8 & 20.5 & 39 & 100.0 \\
\hline \multicolumn{2}{|c|}{$\rho$ value $=0.951$} & \multicolumn{6}{|c|}{$\mathrm{H}_{0}$ Diterima } \\
\hline
\end{tabular}


kecelakaan kerja lebih banyak terjadi pada responden berjenis kelamin wanita dengan persentase sebesar $20.5 \%$, dibandingkan dengan berjenis kelamin pria sebesar 20,0\%.

Dari hasil uji statistik dengan menggunakan Chi Square dengan koreksi kontinuitas dan taraf signifikansi $5 \%$ diperoleh nilai $\rho$ value $=0.951(\rho>0.05)$, sehingga secara statistik dapat dikatakan bahwa tidak ada hubungan antara jenis kelamin dengan terjadinya kecelakaan kerja.

5. Hubungan Antara Shift Kerja Dengan Terjadinya Kecelakaan Kerja

Tabel 4.15. Tabulasi Silang Hubungan Antara Shift Kerja Dengan

Terjadinya Kecelakaan Kerja

\begin{tabular}{|c|c|c|c|c|c|c|c|}
\hline \multirow{3}{*}{ No } & \multirow{3}{*}{ Shift Kerja } & \multicolumn{4}{|c|}{ Kecelakaan Kerja } & \multirow{2}{*}{\multicolumn{2}{|c|}{ Total }} \\
\hline & & \multicolumn{2}{|c|}{$\begin{array}{c}\text { Tidak } \\
\text { Kecelakaan }\end{array}$} & \multicolumn{2}{|c|}{ Kecelakaan } & & \\
\hline & & $\overline{\mathrm{F}}$ & $\%$ & $\mathrm{~F}$ & $\%$ & $\mathrm{~F}$ & $\%$ \\
\hline 1 & Pagi, siang & 56 & 86.2 & 9 & 13.8 & 65 & 100.0 \\
\hline 2 & Malam & 19 & 65.5 & 10 & 34.5 & 29 & 100.0 \\
\hline \multicolumn{2}{|c|}{$\rho$ value $=0.021$} & \multicolumn{6}{|c|}{$\mathrm{H}_{0}$ Ditolak } \\
\hline
\end{tabular}

Berdasarkan tabel 4.15 menunjukkan bahwa proporsi responden yang mengalami kecelakaan kerja lebih banyak terjadi pada responden yang berada pada shift malam dengan persentase sebesar 34.5\%, dibandingkan dengan shift pagi, siang yaitu sebesar 13.8\%.

Dari hasil uji statistik dengan menggunakan Chi Square dengan koreksi kontinuitas dan taraf signifikansi $5 \%$ diperoleh nilai $\rho$ value $=0.021(\rho<0.05)$, sehingga secara statistik dapat dikatakan bahwa ada hubungan antara shift kerja dengan terjadinya kecelakaan kerja.

\section{Hubungan Beban Kerja Dengan Terjadinya Kecelakaan Kerja}

Tabel 4.16. Tabulasi Silang Hubungan Antara Beban Kerja Dengan Terjadinya Kecelakaan

Kerja

\begin{tabular}{|c|c|c|c|c|c|c|c|}
\hline \multirow{4}{*}{ No } & \multirow{4}{*}{ Beban Kerja } & \multicolumn{4}{|c|}{ Kecelakaan Kerja } & \multirow{3}{*}{\multicolumn{2}{|c|}{ Total }} \\
\hline & & \multirow{2}{*}{\multicolumn{2}{|c|}{$\begin{array}{c}\text { Tidak } \\
\text { Kecelakaan }\end{array}$}} & \multirow{2}{*}{\multicolumn{2}{|c|}{ Kecelakaan }} & & \\
\hline & & & & & & & \\
\hline & & $\mathrm{F}$ & $\%$ & $\mathrm{~F}$ & $\%$ & $\mathrm{~F}$ & $\%$ \\
\hline 1 & Ringan & 33 & 91.7 & 3 & 8.3 & 36 & 100.0 \\
\hline 2 & Sedang & 42 & 72.4 & 16 & 27.6 & 58 & 100.0 \\
\hline \multicolumn{2}{|c|}{$\rho$ value $=0.024$} & \multicolumn{6}{|c|}{$\mathrm{H}_{0}$ Ditolak } \\
\hline
\end{tabular}

Berdasarkan tabel 4.16 menunjukkan bahwa proporsi responden yang mengalami kecelakaan kerja lebih banyak terjadi pada responden yang memiliki beban kerja sedang dengan persentase sebesar $27.6 \%$, dibandingkan dengan beban kerja ringan sebesar 8,3\%.

Dari hasil uji statistik dengan menggunakan Chi Square dengan koreksi kontinuitas dan taraf signifikansi $5 \%$ diperoleh nilai $\rho$ value $=0.024(\rho<0.05)$, sehingga secara statistik dapat dikatakan bahwa ada hubungan antara beban kerja dengan terjadinya kecelakaan kerja.

7. Hubungan Antara Unit Kerja Dengan Terjadinya Kecelakaan Kerja

Tabel 4.17. Tabulasi Silang Hubungan Antara Unit Kerja Dengan

Terjadinya Kecelakaan Kerja

\begin{tabular}{|c|c|c|c|c|}
\hline \multirow[b]{2}{*}{ No } & \multirow[b]{2}{*}{ Unit Kerja } & \multicolumn{2}{|c|}{ Kecelakaan Kerja } & \multirow{2}{*}{ Total } \\
\hline & & Tidak Kecelakaan & Kecelakaan & \\
\hline
\end{tabular}




\begin{tabular}{|c|c|c|c|c|c|c|c|}
\cline { 2 - 7 } & & $\mathrm{F}$ & $\%$ & $\mathrm{~F}$ & $\%$ & $\mathrm{~F}$ & $\%$ \\
\hline 1 & Pre Spinning & 23 & 67.6 & 11 & 32.4 & 34 & 100.0 \\
\hline 2 & $\begin{array}{c}\text { Ring Spinning, } \\
\text { Winding }\end{array}$ & 52 & 86.7 & 8 & 13.3 & 60 & 100.0 \\
\hline \multicolumn{2}{|l|}{$\rho$ value $=0.027$} & \multicolumn{3}{|l|}{$\mathrm{H}_{0}$ Ditolak } &
\end{tabular}

Tabel. 4.17.1. CrossTabulation Unit Kerja Dengan Beban Kerja

\begin{tabular}{|c|c|c|c|c|c|}
\hline & & & \multicolumn{2}{|c|}{ Beban Kerja } & \multirow{2}{*}{ Total } \\
\hline & & & Ringan & Sedang & \\
\hline \multirow[b]{2}{*}{ Unit } & \multirow[b]{2}{*}{$\begin{array}{c}\text { Pre } \\
\text { Spinning }\end{array}$} & Count & 12 & 22 & 34 \\
\hline & & $\begin{array}{l}\text { \% within } \\
\text { Unit Kerja }\end{array}$ & $35.3 \%$ & $64.7 \%$ & $100.0 \%$ \\
\hline \multirow[t]{2}{*}{ Kerja } & \multirow{2}{*}{$\begin{array}{c}\text { Ring } \\
\text { Spinning, } \\
\text { Winding }\end{array}$} & Count & 24 & 36 & 60 \\
\hline & & $\begin{array}{l}\text { \% within } \\
\text { Unit Kerja }\end{array}$ & $40.0 \%$ & $60.0 \%$ & $100.0 \%$ \\
\hline
\end{tabular}

Berdasarkan tabel 4.17 menunjukkan bahwa proporsi responden yang mengalami kecelakaan kerja lebih banyak terjadi pada responden yang berada di unit pre spinning dengan persentase sebesar 32,4\%, dibandingkan dengan yang berada di unit kerja ring spinning, winding sebesar 13.3\%. Sedangkan tabel 4.17.1. menunjukkan bahwa proporsi responden dengan beban kerja sedang lebih banyak terjadi diunit pre spinning sebesar 64,7\% dibandingkan dengan unit ring spinning winding yang hanya sebesar $60,0 \%$.

Dari uji statistik dengn menggunakan Chi Square dengan taraf signifikansi 5\% diperoleh nilai $\rho$ value $=0.027(\rho<0.05)$, sehingga secara statistik dapat dikatakan bahwa ada hubungan antara unit kerja dengan terjadinya kecelakaan kerja.

8. Hubungan Kepatuhan SOP Dengan Terjadinya Kecelakaan Kerja

Tabel 4.18. Tabulasi Silang Hubungan Antara Kepatuhan SOP Dengan

Terjadinya Kecelakaan Kerja

\begin{tabular}{|c|c|c|c|c|c|c|c|}
\hline \multirow{3}{*}{ No } & \multirow{3}{*}{ Kepatuhan SOP } & \multicolumn{4}{|c|}{ Kecelakaan Kerja } & \multirow{2}{*}{\multicolumn{2}{|c|}{ Total }} \\
\hline & & \multicolumn{2}{|c|}{ Tidak Kecelakaan } & \multicolumn{2}{|c|}{ Kecelakaan } & & \\
\hline & & $\mathrm{F}$ & $\%$ & $\mathrm{~F}$ & $\%$ & $\mathrm{~F}$ & $\%$ \\
\hline 1 & Patuh & 37 & 78.7 & 10 & 21.3 & 47 & 100.0 \\
\hline 2 & Tidak Patuh & 38 & 80.9 & 9 & 19.1 & 47 & 100.0 \\
\hline \multicolumn{2}{|c|}{$\rho$ value $=0.797$} & \multicolumn{6}{|c|}{$\mathrm{H}_{0}$ Diterima } \\
\hline
\end{tabular}

Berdasarkan tabel 4.18 menunjukkan bahwa proporsi responden yang mengalami kecelakaan kerja lebih banyak terjadi pada responden yang patuh dalam penerapan kepatuhan Standar Operasional Prosedur (SOP) dengan persentase sebesar 21.3\%, dibandingkan dengan responden yang tidak patuh sebesar $19,1 \%$.

Dari uji statistik dengan menggunakan Chi Square dengan taraf signifikansi 5\% diperoleh nilai $\rho$ value $=0.797(\rho>0.05)$, sehingga secara statistik dapat dikatakan bahwa tidak ada hubungan antara kepatuhan SOP dengan terjadinya kecelakaan kerja.

\section{Hubungan Antara Pemakaian APD Dengan Terjadinya Kecelakaan Kerja}

Tabel 4.19. Tabulasi Silang Hubungan Antara Pemakaian APD Dengan Terjadinya Kecelakaan Kerja

\begin{tabular}{|l|l|l|l|}
\hline & Pemakaian APD & Kecelakaan Kerja & \\
\hline
\end{tabular}




\begin{tabular}{|c|c|c|c|c|c|c|c|}
\hline \multirow[t]{2}{*}{ No } & & \multicolumn{2}{|c|}{ Tidak Kecelakaan } & \multicolumn{2}{|c|}{ Kecelakaan } & \multicolumn{2}{|c|}{ Total } \\
\hline & & $\mathrm{F}$ & $\%$ & $\mathrm{~F}$ & $\%$ & $\mathrm{~F}$ & $\%$ \\
\hline 1 & Lengkap & 15 & 78.9 & 4 & 21.1 & 19 & 100.0 \\
\hline 2 & Tidak Lengkap & 60 & 80.0 & 15 & 20.0 & 75 & 100.0 \\
\hline \multicolumn{2}{|c|}{$\rho$ value $=0.919$} & \multicolumn{6}{|c|}{$\mathrm{H}_{0}$ Diterima } \\
\hline
\end{tabular}

Berdasarkan tabel menunjukkan bahwa proporsi responden yang mengalami kecelakaan kerja lebih banyak terjadi pada responden yang lengkap memakai APD dengan persentase sebesar 21.0\%, dibandingkan dengan responden yang tidak lengkap dalan pemakaian APD yaitu sebesar 20,0\%.

Dari uji statistik dengan menggunakan Chi Square dengan taraf signifikansi 5\% diperoleh nilai $\rho$ value $=0.919(\rho>0.05)$, sehingga secara statistik dapat dikatakan bahwa tidak ada hubungan antara pemakaian APD dengan terjadinya kecelakaan kerja.

\section{Hasil Analisis Multivariat}

Analisis multivariat dilakukan dengan menggunakan analisis regresi logistik untuk menentukan variabel yang paling dominan serta untuk menganalisa pengaruh antar variabel penelitian. Analisis regresi logistik merupakan salah satu pendekatan model matematis yang digunakan untuk menganalisis hubungan beberapa variabel bebas dengan sebuah variabel terikat yang bersifat dikotomi atau biner.

Model analisis multivariat yang dilakukan adalah Backward LR. Teknik ini dilakukan dengan memasukan semua variabel ke dalam model dan kemudian dikeluarkan satu persatu dari model berdasarkan kemaknaan statistik tertentu, sampai tidak ada lagi variabel dalam model yang dapat dikeluarkan. Hasil analisis multivariat pada variabel bebas dengan kecelakaan kerja dapat dilihat pada tabel berikut :

Tabel 4.21. Regresi Faktor yang Berhubungan dengan Kecelakaan Kerja

\begin{tabular}{|l|c|c|c|c|c|c|c|c|}
\hline \multirow{2}{*}{ Variabel } & \multirow{2}{*}{ B } & S.E & Wald & \multirow{2}{*}{$\mathrm{dF}$} & Sig & \multirow{2}{*}{ Exp (B) } & \multicolumn{2}{|c|}{ (B) C.l.For EXP } \\
\cline { 5 - 9 } & & & & & & & Lower & Upper \\
\hline Shift Kerja & 1.746 & .650 & 7.229 & 1 & .007 & 5.733 & 1.605 & 20.477 \\
\hline Beban Kerja & 1.571 & .731 & 4.620 & 1 & .032 & 4.812 & 1.149 & 20.158 \\
\hline Unit Kerja & -1.697 & .646 & 6.895 & 1 & .009 & .183 & .052 & .650 \\
\hline Constant & -3.874 & 1.672 & 5.368 & 1 & .021 & .021 & & \\
\hline
\end{tabular}

\section{SIMPULAN DAN SARAN}

1. Responden yang mengalami kecelakaan sebanyak (20,2\%). Kecelakaan kerja ini banyak dialami oleh pekerja yang berusia remaja lanjut (19-21 tahun) yaitu (25.0\%), dengan pendidikan SMP dengan persentase (23.3\%), masa kerja < 6.5 tahun yaitu $(29.8 \%)$, berjenis kelamin wanita yaitu $(20,5 \%)$, shift kerja malam yaitu $(34.5 \%)$, beban kerja sedang yaitu (27.6\%), unit kerja pre spinning yaitu (32,4\%), dengan pekerja yang patuh dalam penerapan SOP yaitu (21.3\%) dan pekerja yang lengkap dalam pemakaian APD sebesar $(21.1 \%)$.

2. Variabel penelitian yang berhubungan dengan terjadinya kecelakaan kerja adalah masa kerja $(p=0.021)$, shift kerja $(p=0.021)$, beban kerja $(p=0,024)$ dan unit kerja $(p=0.027)$. Variabel penelitian yang tidak berhubungan dengan terjadinya kecelakaan kerja adalah usia $(p=0.724)$, pendidikan $(p=0.606)$, jenis kelamin $(p=0.951)$, kepatuhan SOP ( $\mathrm{p}=0.797)$, dan pemakaian APD $(\mathrm{p}=0.919)$.

3. Faktor yang berpengaruh terhadap terjadinya kecelakaan kerja adalah beban kerja, shift kerja dan unit kerja. Setelah diuji dengan menggunakan rumus persamaan logistik maka didapat hasil variabel yang paling berpengaruh adalah shift kerja dengan OR 5.733 yang artinya bahwa responden dengan shift kerja malam mempunyai peluang 5 kali untuk terjadinya kecelakaan kerja dibandingkan pada responden yang berada pada shift pagi dan siang

\section{B.Saran}


Bagi Perusahaan Manufaktur Kota Cirebon

a. Sebaiknya pengarahan mengenai keselamatan kerja (safety induction) bagi pekerja baru lebih difokuskan pada bahaya dan risiko pekerja pada unit kerja yang akan ditempati.

b. Disarankan Bagi perusahaan agar dapat mencukupi ketersediaan APD seperti (topi, masker, kaca mata safety, sarung tangan, baju seragam sesuai ukuran badan pekerja) di unit spinning.

c. Memberikan pelatihan, sosialisasi penggunaan APD secara rutin maupun berkala serta melakukan pengawasan yang lebih intensif tentang penggunaan APD.

d. Menegakan fungsi kontrol dan evaluasi dalam penyediaan APD pada pekerja dan bagi pekerja agar menggunakan APD sesuai dengan SOP yang ada di perusahaan secara konsisten dan sesuai aturan.

e. Sebaiknya perusahaan mengadakan safety talk pada seluruh shift sehingga pelaksanaan safety talk dapat diikuti oleh seluruh pekerja sebelum melakukan pekerjaan.

f. Pada unit kerja yang mempunyai resiko kecelakaan lebih besar seperti di unit pre spinning, perlu dilakukan pengawasan yang lebih intensif.

Bagi pekerja

a. Para pekerja sebaikknya meminimalkan istirahat curian dengan menerapkan pola istirahat yang terstuktur yaitu dengan melakukan istirahat pendek dengan sistem rotasi setiap satu jam atau 8 jam kerja dengan memberikan 3 kali istirahat, minimal 30 menit untuk istirahat makan siang dan 2 kali selama 10 menit untuk istirahat pendek.

b. Agar dapat menggunakan APD sesuai dengan SOP yang ada diperusahaan secara konsisten dan sesuai aturan guna mencegah terjadinya kecelakaan.

Bagi Program Studi Magister Promosi Keselamatan dan Kesehatan Kerja (K3) Universitas Diponegoro

a. Dapat memulai promosi program mengintegrasikan ilmu tentang Keselamatan dan Kesehatan Kerja (K3) pada tataran perusahaan, sehingga bisa menjadi bahan masukan pengambil kebijakan dalam meningkatkan upaya perlindungan pada pekerja.

Bagi Peneliti Lain

a. Perlu dilakukan penelitian lanjutan tentang faktor-faktor lain yang berkontribusi terhadap kecelakaan kerja, misalnya komitmen manajemen perusahaan terhadap keselamatan dan kesehatan kerja. Maupun penelitian lanjutan tentang beban kerja dengan menggunakan metode penilaian pengukuran beban kerja langsung.

\section{DAFTAR PUSTAKA}

1. World Health Organization (WHO). World Health Organization.Manifesto for Safe Communities.Konferensi Internasional Pertama tentang Pencegahan Kecelakaan dan Cidera. Stocklom, Swedia. 20 September 1989:1-7

2. Frank E. Bird, Jr, George L. German, 1985. Practical Loss Control Leadership.Division of Internat.

3. Sahab, Syukri. Dr, MS, Teknik Manajemen Keselamatan dan Kesehatan Kerja, Jakarta: PT. Bina Sumber Daya Manusia, 1997.

4. Pheasant, Stephen. Ergonomic, work and health. USA. Aspen P, Inc, 1991.

5. Pulat, M.B. Fundamental of Industrial Ergomomics. New Jersey: Prentice-Hall, Inc. A. Simon \& Schuster Company Englewood Clifts, 1992.

6. Tarwaka. Dasar-dasar Keselamatan Kerja serta Pencegahan Kecelakaan di Tempat Kerja, Surakarta:Harapan Press, 2012.

7. Santoso, Gempur. Ergonomi Manusia, Peralatan dan Lingkungan, Jakarta:Prestasi Pustaka.OSHA (Ocupational Safey and Health Administration), 2004.

8. Budiono, AM. Sugeng, dan Pusparini,Adriana.Keselamatan Kerja dan Pencegahan Kecelakaan Kerja. Bunga Rampai Hiperkes dan keselamatan Kerja. Edisi 2. Semarang: Universitas Diponegoro, 2003.

9. Houtman IDL, Schaufeli WB, Taris T. Psychische vermoeidheid en werk (mental fatigue and work). Alphen a/d rijn: NWO-prioriten programma PVA/Samsom, 1998.

10. International Loss Control Institute. (Internasional Labour Organization) "World day for safety and health at work 2013” Available from URL: http://www.ilo.org. (cited 2014 Desember 12). 2013.

11. Kementrian Tenanga Kerja dan Transmigrasi RI. Laporan Tahunan. Jakarta.2012.

12. Jamsostek. Kecelakaan Kerja.Available from URL : http://www.jamsostek.co.id. (cited2014 Desember 20). 2008

13. Dauly, Ahmad Fristiyan. Faktor-faktor Yang Berhubungan Dengan Kecelakaan Kerja Pada Buruh Konstruksi Di PT. PP (Persero) Proyek Tiffani Apartemen Kemang Jakarta-Selatan Tahun 2010(Skripsi). Universitas Islam Negeri Syarif Hidayatullah Jakarta. 2010.

14. Wildan, Zamani. Identifikasi Bahaya Kecelakaan Unit Spinning I Menggunakan Metode HIRARC Di PT. Sinar Pantja Djaja.Unnes Journal Of Public Heatlh, Vols. 3 (1) (2014) 2252-6528.

15. Ramli, Soehatman. Sistem Manajemen Keselamatan Kesehatan Kerja OHSAS 18001. Jakarta: Dian Rakyat. 2009. 
16. Profil Perusahaan Manufaktur Kota Cirebon. Tahun 2014.

17. Sumarni, Murti danSoeprihanto, J. Pengantar Bisnis (Dasar-dasar Ekonomi Perusahaan) Edisi 5. Yogyakarta: Liberty. 1998.

18. Heizer,J danRender, B. Operation Management. Edisi 7. Jakarta: Salemba Empat. 2005.

19. Subagyo, Asmanto.Proses Manufaktur BenangDengan Sistem Rotor. Edisi 1.Yogyakarta: Graha Ilmu.2003.

20. S. Syarif Iskandar dkk, Bahan Ajar Praktikum Teknologi Pemintalan 1, Sekolah Tinggi Teknologi Tekstil, 2005

21. Heinrich, H. W., Peterson, D., and Roos, N. A Safety Management Approach in Industrial Accident Prevention. New York: McGraw-Hill Book Company 1996.

22. OHSAS 18001:2007. Occupational Health and Safety Management System - Guideline For The Implementation of OHSAS 18001.

23. Undang-Undang Republik Indonesia Nomor 3 Tahun 1992.Tentang Jaminan Sosial Tenaga Kerja. Jakarta. 1992.

24. Suma'mur. P.K. Keselamatan kerja dan pencegahan kecelakaan. Jakarta: CV Haji Masagung. 2009.

25. Colling, David A. "Industrial Safety Management and Technology". Pentice Hall Inc, 1990.

26. National Center For Injury Prevention and Control. CDC Injury Fact Book. Atlanta (GA): Centers For Disease Control and Prevention, 2006.

27. Tariq, S Abdelhamid.and John G Everett. Identifying Root Causes of Construction Accidents. Juornal of American Society Of Civil Engineers (ASCE). Construction Engineering and Management, Vol. 126, No. 1, pp. 52-60. 2000.

28. Bird, Frank E., Jr., and Germain, George L. Loss Control Management: Practical Loss Control Leadership, Revised Edition. Det Norske Veritas (U.S.A), Inc. Loganville, Georgia.2006:9-14.

29. ILO, Pencegahan kecelakaan. Jakarta:PT. Pustaka Binaman Pressindo.1989.

30. Notoatmodjo, Soekidjo. Ilmu Perilaku Kesehatan. Jakarta: Rineka Cipta. 2003.

31. Green, Lawrence W. Health Promotion Planning: Educational and Environmental Approach. Secon Edition. Mayfield Publishing Company. USA. 1991.

32. Ghosh, Apurna Kumar, etc. Journal of Occupational Health Vol. 46: Relationship of Working Condition and Individual Characteristics to Occupational Injuries: A Case-Control Study in Coal Miners. Department of Mining Engineering, National Institute of Technology. Faculte de Medecine, France. 2004: 470-478.

33. Depkes RI. Profil Kesehatan Indonesia. Jakarta: 2009.

34. Hurlock. Psikologi Perkembangan : Suatu Pendekatan Sepanjang Rentang Kehidupan. Erlangga. Surabaya. 2002.

35. Aderaw, Zewdie., etc. Journal Of Tropical Medicine Vol. 2011: Clinical Study Determinants of Occupational Injury: A Case Control Study Among Textile Factory Workers in Amhara Regional State, Ethiopia. Hindawi Publishin Corporation. Ethiopia. 2011.

36. Departemen Pendidikan dan Kebudayaan. 2001. Kamus Besar Bahasa Indonesia. Jakarta: Balai Pustaka

37. K, Astrand P And Rodahl. Text Book of work Physiology. Third Edition. New York ; Mc. Graw Hill Book Co, 1986.

38. Santoso, Budi Slamet. Analisa kecelakaan akibat kerja pada karyawan PT. Bakrie Pipe Industries, Bekasi Tahun 1998.(Skripsi).1999.

39. Lewis G, Wessely S. The Epidemiology Of Fatigu; More Question than Answer. 92-97. J. Epidemiology Community Health, 1992, Vol.46.

40. Colligan, roger R. Rosa Michael J. Plan language about shiftwork. Ohio : U.S Department of Health and human Services Public Health Service, Centers for dieseases control and prevention National Institute for Occu [ ational safety and Health Division of Biomedical and Behavioral Science, Education and Information Division Cincint], 1997.

41. Tarwaka. Ergonomi Industri. Dasar-dasar pengetahuan ergonomi dan aplikasi di tempat kerja. Surakarta: Harapan Press. 2010.

42. Sanders S, M, McCormick J, E. Human Faktors in Engineering and Design. S.I.: McGRAW-Hill Inc. International editions, 1992

43. Kroemer, K.H.E. Grandjean, E. Fitting thetask to the human; A Textbook of Occupational ergonomics 5th Ed. Taylor \& Francis Routledge, 1997.

44. Wignjosoebroto, Sritomo. Ergonomi, Study Gerak dan Waktu, Teknik Analisis untuk Peningkatan Produktivitas kerja. Jakarta : PT.Guna Widya, 1995.

45. Pulat, M.B. Fundamental of Industrial Ergomomics. New Jersey ; Prentice-Hall, Inc. A. Simon \& Schuster Company Englewood Clifts, 1992.

46. Grandjean, E. Fitting the task to man, 4th Edt. London: Taylor \& Francis Inc, 1995.

47. Adams, J. A. Human Factors Engineering. New York, NY, USA: MacMillian Press. 1989

48. Jawawi, Iskandar.Beberapa Faktor Resiko Yang Berhubungan Dengan Tingkat Kecelakaan Kerja di PT. Hok Tong Pontianak (Pabrik Crum Rubber). (Skripsi) Universitas Diponegoro.Semarang. 2008.

49. Rodahl, Kaare. The Physiology of work. London, New York, Philadelphia: Taylor \& Francis, 1989.

50. Bennett. NB Silalahi dan RumoundangB Silalahi. Manajemen Keselamatan dan Kesehatan Kerja.Jakarta: PT. Pustaka Binaman Pressindo.1985

51. Arifin, Zainal. Faktor-faktor yang berhubungan dengan kecelakaan kerja di PT. Bukaka Teknik. (Skripsi). Universitas Indonesia. Jakarta. 2005.

52. Perusahaan Manufaktur Kota Cirebon. Bagian Personalia. Cirebon. 2014.

53. Notoatmodjo, Soekidjo. Metodologi Penelitian Kesehatan. Jakarta: PT. Rineka Cipta. 2002.

54. Budiarto. Metodologi Penelitian Kesehatan Masyarakat dan Kedokteran.Jakarta: Rineka Cipta.2001.

55. Sugiyono. Statistika Untuk Penelitian. Bandung: Alfabeta. 2009.

56. Cottrell BH. An Updated Review of Evidence To Discourage Douching. MCN, Am. J. Matern. Child. 
Nurs.,35(2):102-107;108-109.

57. Tresnaningsih E. Ruang Lingkup dan Metode Kesehatan Kerja. Dalam Materi Kesehatan Kerja. Direktorat Bina Peran Serta Masyarakat Direktorat Jenderal Pembinaan Kesehatan Masyarakat Departemen Kesehatan Republik Indonesia. Jakarta, 1993.

58. Robin, S.P. Rerilaku Organisasi (Pujaatmaka, H\& Molan, B, Penerjemah). Edisi 9. Jakarta: PT. Indeks Gramedia. 2003.

59. Layuk, Semuel. Faktor-faktor Yang Mempengaruhi Terjadinya Kecelakaan Kerja di PT G.E. Lighting Indonesia Sleman Yogyakarta. (Thesis). UGM. Yogyakarta. 2002.

60. Rante, Ada Yeremia. Pengaruh tipe kepribadian, umur, masa kerja, dan tingkat pendidikan tenaga kerja terhadap kecelakaan kerja di PR. General Electric Lighting Indonesia. (Thesis). UGM. Yogyakarta. 2006.

61. Romi, Kajian Faktor-faktor yang berhubungan dengan kecelakaan kerja di PT. Guanusa Utama Fabricans Grenyang. (Skripsi). Universitas Indonesia. Jakarta. 2005.

62. Tulus, MA. Manajemen Sumber Daya Manusia. Jakarta: Gramedia Pustaka Utama. 1992.

63. Silalahi, Bennet W. B. \& Silalahi Ramondang B. Manajemen Keselamatan danKesehatan Kerja, Seri Manajemen No. 112 Jakarta: PT. Pertja: 1991.

64. Sukailan, M. Analisis faktor-faktor kecelakaan kerja di PT. Sari Husada Tbk

65. Jogjakarta. (Thesis)Universitas Gajah Mada.Yogyakarta. 2004.

66. Suryanto. Gender? Apa itu?. Suryanto personal blog. Psykology For Life. Diunduh tanggal 20 Juni 2015.

67. Jaji. Faktor Manusia dan Faktor Pekerjaan Berhubungan dengan Penyebab Kecelakaan Kerja pada Pekerja Kemplang (Home Industry) di Desa Tebing Gerinting Tahun 2012.Jurnal Kesehatan Masyarakat. 2012: Vol 3 (1): 2086-6380.

68. Wicken, C. D., Lee, J. D., Liu, Y., Becker, S. E. G., An Introduction To Human Factors Engineering, Prentice Hall, New Jersey.2004.

69. Sharpe, J. Shift work and long hours: risky business, Rock Product. 2007.

70. Riyadina, Woro.Kecelakaan Kerja Dan Cedera Yang Dialami Oleh Pekerja Industri Di Kawasan Industri Pulo Gadung Jakarta. Jurnal Kesehatan Masyarakat. 2007. vol 11 (1); 25 - 31.

71. Sukamto. Faktor-faktor yang berhubungan dengan kecelakaan kerja pada Seismic survey di unit Geodata acqusition (GDA) PT. Elnusa Geosains tahun 2001-2003. (Skripsi). Universitas Indonesia. Jakarta. 2004.

72. Kurniawati, Wijayanti. Hubungan Praktik Penerapan Standar Operasional Prosedur (SOP) Dan Pemakaian Alat Pelindung Diri (APD) Dengan Terjadinya Kecelakaan Kerja Pada Perawat Unit Perintologi Di RSUD Tugurejo. Semarang.(Skripsi). Universitas Dian Nuswantoro. 2014.

73. Tarwaka. Keselamatan dan Kesehatan Kerja, Menejemen dan Implementasi K3 di Tempat Kerja. Surakarta: harapan Press. 2008

74. Tarwaka. Keselamatan dan Kesehatan Kerja, Menejemen dan Implementasi K3 di Tempat Kerja. Surakarta: harapan Press. 2008.

75. Wibisono, Bayu. Faktor-faktor Yang Berhubungan Dengan Kejadian Kecelakaan Kerja Pada Pekerja Tambang Pasir Gali Di Desa Pegiringan Kabupaten Pemalang Tahun 2013. (Skripsi). Universitas Dian Nuswantoro.2013. 